\title{
SURGIMENTO DA IDÉIA DE LIBERDADES ESSENCIAIS RELATIVAS À INFORMAÇÃO \\ - A "AREOPAGITICA" DE MILTON" -
}

\author{
Airton Cerqueira Leite Seelaender \\ Bolsista da FAPESP e orientando do Professor E. Ricardo Lewandowski, do \\ Depto. de Direito do Estado da Faculdade de Direito da Universidade de S. Paulo
}

\begin{abstract}
Resumo:
O ponto de partida de toda a reflexão, por parte da Teoria Política, acerca das liberdades essenciais relativas à informação foi o surgimento, na Inglaterra seiscentista, da Areopagitica de John Milton. Com tal obra, que influenciou enormemente o pensamento jurídico democrático na era do triunfo do Constitucionalismo, o escritor britânico legou à posteridade os argumentos e teses que viriam a constituir não só as principais alegações hoje empregadas na crítica aos mecanismos estatais de censura, mas também a base da própria concepção liberal de direito de informação. No momento em que se torna evidente a necessidade de sé superar esta concepção, cumpre proceder a uma releitura do discurso de Milton, de modo a resgatar o seu conceito original de liberdade de informação, em verdade mais amplo que o liberal e bem mais adequado do que este para servir de referencial aos legisladores do mundo contemporâneo.
\end{abstract}

\begin{abstract}
:
The starting-point, in the field of Political Theory, of every reflection about the essential liberties concerning information was the publication of John Milton's Areopagitica in 17th century England. With this work, which considerably influenced the democratic juridical thought in the age of the triumph of Constitutionalism, the British writer bequeathed to posterity propositions and theses that would not only become the principal arguments used nowadays for criticizing the State mechanisms of censorship, but also the basis of the liberal conception of the law of information. In this particular moment, when the necessity of transcending this conception becomes evident, a new reading of Milton's discourse seems imperative in order to restore his original idea of the liberty of information, which is actually broader and certainly more adequate as intellectual foundation for today's legislators than the traditional liberal concept.
\end{abstract}

- O texto ora publicado constitui resultado de pesquisas realizadas pelo autor em fins da década de 80, na condiçāo đe bolsista da Fundação de Amparo à Pesquisa do Estado de São Paulo (FAPESP). 
O nascimento da idéia de liberdades essenciais relativas à informação, embora já prenunciado nas doutrinas de alguns reformadores da Idade Média e do século XVI, deu-se, a rigor, apenas na primeira metade do século XVII, com o advento da Areopagitica ${ }^{1}$ de Milton. Publicado em 1644, esse discurso, cujo tema principal era a inaceitabilidade da censura prévia, representou o marco inicial de toda uma longa e rica tradição de questionamento da legitimidade dos procedimentos utilizados pelos governantes para cercear a divulgação de informações e opiniões contrárias aos seus interesses. Não há, pois, nada de surpreendente no fato de que em Areopagitica se encontrem as raízes mais longínquas, tanto históricas quanto teóricas, do conceito moderno de direito à informação.

Para que se criem idéias políticas novas, é preciso que uma dada sociedade, ou parte dela, já não mais se satisfaça com aquelas com que conta. Assim sendo, na maioria das vezes os grandes surtos criadores no pensamento político são resultado de alterações substanciais da realidade social, em períodos de transição estes, afinal, por sua própria natureza tendem a ocasionar a aparição de novas indagações. A concepção de liberdades relativas à informação e a percepção de sua necessidade só poderiam, por conseguinte, ter surgido, no século XVII, onde além de se verificarem inúmeras outras condições estivesse ocorrendo uma crise capaz de tornar as pessoas inclinadas à busca de soluções originais para os seus problemas. Ao se estudar Areopagitica, portanto, deve-se atentar para a sua relação com o ambiente bastante singular do qual surgiu, mesmo porque as grandes obras não constituem meras produções individuais como explica Lucien Goldmann, ${ }^{2}$ na realidade elas são

"simultaneamente colectivas e individuais, uma vez que a visão de mundo a que correspondem foi elaborada durante vários anos $e$, por vezes, durante diversas geraçōes pela colectividade, mas sendo que o seu autor é o primeiro ou, pelo menos, um dos

1. O título desse opúsculo de Milton foi inspirado no Logos Areopagiticos do orador greco Isócrates (436 a.C. 338 a.C.), que também era um discurso feito para ser lido, não para ser ouvido. Isócrates nele defendia o restabelecimento da democracia em Atenas, com a restauração do tribunal do Areópago - daí o título de sua obra.

2. Lucien Goldmann, Epistemologia e filosofia politica, Lisboa, Presença, 1982, p. 32. 


\section{primeiros a exprimi-la a um nivel de coerência avançado".}

Areopagitica não foi apenas uma criação de Milton; ela foi também fruto da Inglaterra de seu tempo. Para que se atinja um nível razoável de compreensão do desenvolvimento histórico da idéia de liberdade de informação, nos planos da Teoria Política e do Direito, faz-se, pois, indispensável, antes de mais nada, apreender as razóes que levaram esta mesma idéia a aflorar onde, quando e $d a$ forma em que o fez. O que não implica de modo algum - veja-se bem - ignorar os elementos estritamente pessoais impressos em Areopagitica pelo seu autor. Por mais que se subestime John Milton, tentar apagar de suas obras a sua marca pessoal constituiria, mais do que uma temeridade do ponto de vista analítico, uma tarefa na prática realmente impossível.

A idéia de liberdade de informação tomou corpo, clara e distintamente, na Inglaterra do século XVII, porque nesta se reuniram condições extremamente favoráveis à sua geração. Ao longo dos reinados de Jaime I Stuart e de seu filho Carlos, haviam-se verificado simultaneamente o fenômeno da perda de prestígio das autoridades tradicionais e uma valorização crescente do indivíduo, esta última com base nas novas concepções religiosas e impulsionada pelas transformações ocorridas no seio da sociedade desde os tempos dos Tudor. Criara-se, dessa forma, um campo fértil para o desenvolvimento e a propagação de idéias políticas favoráveis à liberdade individual - a impopularidade de uma dinastia inepta e a aversão cada vez maior que se devotava à Igreja oficial ${ }^{3}$ haviam acarretado a aparição de um anseio de se reverem os próprios fundamentos da Autoridade arbitrária. A Guerra Civil e a execução do rei seriam a um tempo causa e consequiência do recrudescimento deste anseio; ambas tanto levariam inúmeros ingleses a abandonarem o fetichismo da Autoridade quanto forçariam toda uma nação a repensar as relações entre governantes e governados.

E impossível avaliar precisamente o grau de influência da Reforma, enquanto grande movimento de renovação das mentalidades, na progressiva

3. Havia então uma grave crise da autoridade da Igreja Anglicana. Já em 1589 o bispo Cooper falava, em sua Admoestação ao Povo da Inglaterra, de um "repulsivo desdém, ódio e aversāo que a maior parte dos homens tem em nossos dias (...) pelos ministros da Igreja de Deus" (cf. Christopher Hill, O mundo de ponta-cabeça, São Paulo, Cia. das Letras, 1987, p. 45). 
conscientização dos ingleses do século XVII acerca das questões concernentes às liberdades individuais, na esteira da qual ganharia forma o que hoje se reconhece como a primeira expressão da idéia de liberdade de informação. $O$ certo é que, difundindo a opinião de que todo homem tinha o direito de pensar por si mesmo com o auxilio das Escrituras, e falhando por vezes em estabelecer esquemas repressivos eficientes a ponto de assegurarem a plena uniformização das crenças religiosas, as novas seitas e Igrejas acabaram contribuindo involuntariamente, com o seu advento, para que na prática passasse a existir na Inglaterra uma relativa margem de autonomia individual em questões de consciência. Desnecessário acrescentar que, uma vez adquirida tal margem, algumas pessoas puderam perceber quase que de imediato a sua imprescindibilidade deu-se, assim, o primeiro passo significativo no caminho que conduziria às posições sustentadas em Areopagitica. A experiência de uma relativa liberdade religiosa teria ensejado, dessa forma, um processo de reflexão que levaria, sucessivamente, a uma formulação mais ampla da liberdade de consciência, à idéia de liberdade de expressão esta vinculada indissoluvelmente, como viria a mostrar no século XIX John Stuart Mill, ${ }^{4}$ àquela e enfim à de liberdade de imprensa, cuja defesa seria delineada pela primeira vez na obra de John Milton.

Nâo só no plano religioso, contudo, se assentaram os pilares da mudança de mentalidade que prepararia a construção, no pensamento político seiscentista, da idéia de liberdade de publicação, núcleo da noção de liberdade de imprensa. Faz-se indispensável levar em conta, igualmente, um outro fator decisivo, este de ordem material: no século XVII muitos ingleses, no campo e na cidade, detinham uma condição social e econômica que lhes possibilitava ter um alto grau de independência pessoal. ${ }^{5}$ Era a época do "squire" e do "yeoman"6 de caráter insubmisso, da decadência das corporações e seus mecanismos de controle, da introdução paulatina na visão de mundo de uma sociedade daquele

4. cf. John Stuart Mill, Da liberdade, Sāo Paulo, IBRASA, 1963, p. 15.

5. cf. George Macaulay Trevelyan, English Social History, Harmonđsworth, Penguin Books, 1986, p. 255-56.

6. Os "yeomen" eram pequenos proprietários rurais; os "squires", latifundiários, em regra bastante influentes em seus respectivos distritos. 
"individualismo possessivo" de que fala Macpherson. ${ }^{7}$ Por trás da criação do ambiente propício à concepção de novas liberdades individuais no qual veio a se originar, historicamente, a idéia de liberdade de informação, houve, pois, também uma razão de natureza sócio-econômica, cujo papel não deve ser de modo algum menosprezado.

A concorrência de tantas condições favoráveis na Inglaterra não teria, porém, bastado para ensejar a elaboração da idéia supramencionada, não estivesse a Europa assistindo então a um lento propagar do princípio da tolerância um fenômeno provocado principalmente, diga-se de passagem, pela crescente conscientização de que as questões religiosas não deveriam nem poderiam ser decididas através do emprego da força. ${ }^{8}$ Seguindo uma tendência que desconhecia fronteiras, inúmeros ingleses se tornaram, assim, a partir do final do período Tudor, partidários de uma convivência pacífica baseada na admissão de um pluralismo religioso que, na conjuntura da época, correspondia a um verdadeiro pluralismo ideológico - tal foi o caso de pessoas como John Milton, ou como aquele Roger Williams que, tendo emigrado para Massachussetts, de lá acabou sendo expulso por defender a liberdade de consciência contra o poder civil. ${ }^{9}$ Embora não se devam cometer exageros na estimativa dos progressos feitos pela doutrina da tolerância na Inglaterra no século XVI, ${ }^{10}$ há que se perceber que, sem estes, jamais se teria conseguido elaborar uma Areopagitica contra a censura prévia e em favor da liberdade de publicação. Ainda que não estivesse madura a ponto de incorporar o princípio da tolerância ao seu senso comum, a sociedade inglesa de então já o estava em grau suficiente para poder produzir uma obra na qual se concebesse uma liberdade

7. Crawford Brough Macpherson, A teoria politica do individualismo possessivo, Rio de Janeiro, Paz e Terra, 1979. Para Macpherson, o "individualismo possessivo" seria a ideologia fundada na concepção de cada pessoa como proprietária de si mesma e de suas próprias capacidades. Tal concepção estaria presente no pensamento de vários autores liberais nomeadamente no de Locke - bem como no de filósofos de outras tendências, como Hobbes.

8. cf. G. R. Elton, A Europa durante a Reforma: 1517-1559, Lisboa, Presença, 1982, p. 224.

9. cf. Trevelyan, ob. cit., p. 225.

10. Um pouco de prudência se faz aqui conveniente. Embora a tendência histórica fosse então no sentido de uma maior tolerância, é preciso lembrar que um certo Thomas Case ainda expressava os receios de inúmeros ingleses, ao advertir, em discurso na Câmara dos Comuns, que o que então se chamava de "liberdade de consciência" poderia logo se converter "em liberdade de terras, em liberdade de casas, em liberdade de esposas". (cf. Hill, ob. cit., p. 112). 
fundada, em última análise, nesse mesmo princípio - e foi disso que decorreu, sem sombra de dúvida, seu pioneirismo no campo do pensamento político que é objeto de nosso trabalho.

Dada esta visão mais panorâmica, cumpre agora enfocar diretamente Milton e as circunstâncias específicas que o levaram a abrir novo espaço de reflexão para a Teoria Política. Deixar de fazê-lo, além de caracterizar um reducionismo inaceitável, implicaria mesmo a impossibilidade de se compreender a profunda ligação existente entre a idéia de liberdade de imprensá, em sua forma embrionária, e a da "liberdade de saber" ("liberty to know") miltoniana - uma ligação, por sinal, cuja análise imprescindível nos convida a questionar os modos tradicionais de justificação da liberdade de imprensa, ao trazer à luz mais uma evidência, a da origem histórica, de que a razão de ser desta liberdade é um tanto diversa daquela que lhe é geralmente atribuída.

John Milton (1608-1674) viveu em uma das fases mais conturbadas da história inglesa, tendo participado ativamente das lutas políticas de seu tempo. Deflagrada a Guerra Civil, tomou o partido do Parlamento, cuja maioria presbiteriana liderava a oposição a Carlos I. Convertendo-se pouco a pouco em um dos principais ideólogos da luta contra os Stuart, o escritor não tardou em se decepcionar com os novos detentores do poder; inclinou-se, por conseguinte, cada vez mais para uma postura de apoio aos chamados independentes, dos quais ora se distanciaria, ora se aproximaria, tendo chegado mesmo a servir ao governo de Cromwell. Com a Restauração, Milton foi preso, mas não executado. Libertado, pôde dedicar o restante de seus dias à literatura, sabendo-se impotente diante de um regime que apenas o tolerava.

Há certa polêmica entre os autores quanto à qualidade e não, note-se, quanto à relevância - de Milton como pensador político. Denis Saurat, ${ }^{11}$ cuja obra sobre o escritor inglês continua um referencial obrigatório, toma-lhe a defesa realçando a coerência que julga perceber entre as várias manifestações do pensamento miltoniano, buscando com isso demonstrar a sistematicidade deste; Kurt Schilling, ${ }^{12}$ por sua vez, contesta a validade do procedimento de Saurat, e

11. cf. Denis Saurat, Milton, Man and Thinker, London, J.M. Dent \& Sons, s.d., p. 152-61.

12. Kurt Schilling, História das idéias sociais, $2^{\mathrm{a}}$ ed., Rio de Janeiro, Zahar, 1974, p. 224. 
resgata o cruel comentário, sobre Milton e seu inimigo Salmasius, feito por Thomas Hobbes, o qual afirmava não saber em qual dos dois encontrava a linguagem mais bela e os piores motivos. Em que pesem, porém, todas estas divergências, não há como não reconhecer a contribuição das idéias do poeta e ativista puritano para o avanço das liberdades na Inglaterra - onde serviram inclusive para justificar intelectualmente a Revolução e a decapitação do Rei - e na América, onde - é ponto pacífico - exerceram uma enorme influência. Há que se levar em conta, ao lado disto, que Areopagitica, examinada à parte, possui indubitavelmente uma lógica interna, não sendo cabível lhe estender as críticas desdenhosas e precipitadamente generalizantes feitas por Schilling ao pensamento político de seu autor. ${ }^{13} \mathrm{Com}$ efeito, reconhecida por unanimidade como a mais convincente dentre todas as obras escritas por John Milton no campo da reflexão política, Areopagitica ainda figura no seleto conjunto dos livros que, por expressarem no nível máximo de coerência as idéias resultantes da sociedade e do período em que surgiram, conseguem conservar o interesse através das épocas, podendo sobreviver mesmo à parcial obsolescência de seus temas e argumentos.

Se na Idade Média e no século XVI algo como que uma elevação do homem à maioridade servira, nas doutrinas de alguns reformadores, para justificar o livre acesso a um livro tido então por repositório de informações verdadeiras, no século XVII se realizou, com Milton, uma ampliação desse modelo argumentativo de modo a abarcar não apenas uma questão na esfera religiosa, mas sim toda e qualquer situação em que se pudesse identificar uma transmissão de informações e de opiniões. Herdeiro legítimo de Hus, de Lutero e do "divino e admirável espírito de Wycliffe", ${ }^{14}$ John Milton elaborou, visando a demonstrar a necessidade da liberdade de informação, uma construção teórica análoga à utilizada pelos primeiros na polêmica acerca da tradução das Escrituras, do que resultou constarem em ambas elementos semelhantes, quando não comuns. Da negação da onisciência da Autoridade e de uma valorização do indivíduo convergiu o poeta inglês, igualmente, para uma condenação dos meios

13. Ob. cit., p. 224. Segundo o autor, é "discutivel do ponto de vista histórico querer encontrar" em John Milton "(...) uma idéia sistemática, isenta de contradições e coerente"

14. John Milton, Areopagitica. In: Charles W. Eliot (org.), The Harvard Classics, New York, P.F. Collier \& Son, 1909, v. 3, p. 234. 
empregados pelos poderosos para reter o fluxo de informações; rejeitando, assim como os três teólogos, as avaliações pessimistas da capacidade do homem comum, Milton acabaria também por reivindicar o respeito das autoridades ao que se lhe afigurava como o mínimo indispensável de autonomia individual, sem o qual o homem, ser pensante, teria a sua própria maturidade posta em questão:

"Que vantagem há em ser um homem, em relação a ser um menino na escola, se apenas escapamos da palmatória para cair sob a vara de um 'Imprimatur'?"15

A dívida de Milton para com os reformadores é evidente - acaso se poderia admitir como simples coincidência a similitude das construções teóricas a que acima se aludiu? $\mathrm{Na}$ verdade, jamais se conseguiria entender as posições assumidas por Milton em Areopagitica, sem um exame prévio dos vínculos entre estas e a religião protestante do escritor inglês. ${ }^{16} \mathrm{~A}$ tendência à valorização do indivíduo que a idéia do sacerdócio universal traz implícita, por exemplo, certamente esteve na raiz da ocorrência de fenômenos como o da aparição, no pensamento miltoniano, de uma inclinação à defesa das liberdades dos cidadãos; suscitando, a partir da desmistificação da figura do clérigo, uma crescente antipatia pelo autoritarismo na Igreja, a inspiração igualizadora do princípio do sacerdócio de todos os crentes acabou por favorecer, em virtude da profunda simbiose entre os poderes espiritual e temporal na Inglaterra Stuart, o desenvolvimento, em pessoas como John Milton, de um sentimento de aversão pelos tiranos, desrespeitadores das liberdades. ${ }^{17}$ É necessário observar, aliás, que o poeta não só recebeu e assimilou da tradição protestante o princípio

15. Milton, ob. cit., p. 222. "What advantage is it to be a man over it is to be a boy at school, if we have only escaped the ferular, to come under the fescu of an 'Imprimatur'?".

16. Não deixa de ser oportuno, aliás, lembrar aqui mais um indício da ligação entre o pensamento de Milton e o dos três reformadores: a posição do primeiro em face da questão do acesso ao repositório de informaçōes verdadeiras representado pela Bíblia. $O$ escritor puritano, ao dizer que "todo o crente tem um direito de interpretar as Escrituras por si mesmo" (apud Saurat, ob. cit., p. 153), revelava claramente haver assimilado da tradição protestante a construção teórica daqueles teólogos que, descartando a pressuposição autoritária da insensatez do homem comum, haviam reconhecido neste como que um direito de dispor do acesso supracitado.

17. cf. Saurat, p. 160. Milton opunha à idéia de tirano a de um "verdadeiro líder", o qual, embora pudesse dispor de poderes quase que absolutos, ao menos respeitaria "a liberdade do povo", que para o escritor se restringiria à liberdade intelectual e religiosa. 
mencionado, como ainda o levou às últimas conseqüências. Com efeito, para ele, até "o mais mesquinho dos artesãos tinha o direito de ser pregador", 18 pois que todos os fiéis seriam sacerdotes, não passando os chamados "sacerdotes" de usurpadores abjetos. ${ }^{19} \mathrm{O}$ corolário de tal ponto de vista foi, é óbvio, aquela crença na "igualdade do valor moral de todos os seres humanos" que, segundo Macpherson, teria sido "nitidamente fundamental no pensamento político puritano". ${ }^{20}$ Daí porque, ao se analisar Areopagitica, se faz tão conveniente recordar as origens religiosas dos pressupostos de sua argumentação - o mais importante destes pressupostos, afinal, foi justamente esta crença puritana, que corroeu os pilares da justificação, por meio de preconceitos elitistas, da prática de se impedir que as informações chegassem ao homem comum, visto como "inferior" aos iluminados membros dos grupos dominantes.

Um outro importante ponto de contato entre o crente e o pensador político em John Milton foi a sua noção de liberdade, comum tanto às suas reflexões teológicas quanto a obras como Defensio pro populo Anglicano e Areopagitica. Nascida, afirma Kurt Schilling, ${ }^{21}$ do dogma da predestinação de Calvino, a concepção miltoniana da liberdade teve sempre por núcleo a idéia de que os "eleitos" deveriam ser livres de quaisquer restrições. ${ }^{22}$ Não obstante a adesão de Milton à tese do livre-arbítrio, ${ }^{23}$ ao que tudo indica esta idéia central logrou sobreviver em seu pensamento, adaptando-se e se mantendo como fulcro de toda a sua argumentação em favor das liberdades. Por este motivo, não é difícil encontrar em obras de Milton, nem mesmo nas posteriores à sua mudança de substrato filosófico, passagens semelhantes à que vem a seguir extraída de Areopagitica - na qual se prega o respeito a uma liberdade (no caso, a "liberdade de saber") através da rejeição de todo e qualquer controle ou restrição sobre os "eleitos":

18. Hill, ob. cit., p. 377.

19. cf. Saurat, ob. cit., p. 154.

20. Macpherson, ob. cit., p. 14.

21. Schilling, ob. cit., p. 224.

22. cf. Hill, ob. cit., p. 168.

23. cf. Saurat, ob. cit., p. 19 e p. 63. 
"Para' os puros todas as coisas sāo puras, não apenas as carnes $e$ bebidas, como ainda todas as formas de conhecimento, refiram-se elas ao bem ou ao mal" 24

O grande mérito de Milton, enquanto pensador político, não residiu, todavia, no fato de ter sabido se valer de seus conhecimentos de teologia à hora de enfrentar a problemática da liberdade individual em face do Estado - esse tipo de recurso, aliás, nada apresentava de original na Europa do século XVII. O que tornou o poeta inglês um referencial obrigatório foi, na verdade, a sua superação das limitações inerentes à visão de mundo de uma época dominada pelo espírito de seita. Com efeito, sem tal superação não lhe teria sido possível conceber uma idéia de liberdade de informação digna deste nome, um conceito que se referisse a todas as pessoas independentemente de credo e que extravasasse do campo religioso para atingir igualmente os planos político e cultural, podendo nestes ter vida própria. Como bem lembra Hill, ${ }^{25}$ embora Milton geralmente fundasse na crença de que Cristo residia nos fiéis a defesa das liberdades destes, em Areopagitica o escritor exigiu o respeito à liberdade de informação não apenas dos fiéis, mas sim de todos os homens. As liberdades de expressão e de publicação, e a própria "liberdade de saber" ("liberty to know") encaradas por Milton, por sinal, como meras facetas de uma mesma e única "liberty"26 correspondiam, assim, para ele, não a um direito decorrente da condição de cristão, mas a um direito do homem, logo de todos os homens. Como um seu contemporâneo, o líder nivelador John Lilburne, Milton mostrava, com Areopagitica, haver finalmente percebido que as liberdades civis teriam de ser para todos, ou acabariam não sendo para ninguém. ${ }^{27}$

Ao se proceder à análise de Areopagitica, portanto, não cabe subestimar, ante a insistência de Milton em buscar sustentação teológica a seus argumentos,

24. Milton, ob. cit., p. 210. "To the pure all things are pure, not only meats and drinks, but all kind of knowledge whether of good or evil". A traduçāo da passagem é de Renato Janine Ribeiro, tendo sido extraída da p. 377 do livro de Hill.

25. Hill, ob. cit., p. 377.

26. cf. Milton, ob. cit., p. 238.

27. Sobre Lilburne, cf. Macpherson, ob. cit., p. 154. 
a qualidade dos argumentos em si, através de um julgamento precipitado e comprometido pelo preconceito. Primeira obra a estabelecer claramente uma justificação da liberdade de informação, Areopagitica conserva ainda, desconsiderado o elemento religioso, uma inequívoca atualidade, que se comprova de modo irrefutável na sobrevivência dos pontos de vista de seu autor sob a forma de verdadeiros lugares-comuns no discurso político contemporâneo.

A formulação por John Milton de um conceito de liberdade de informação deu-se em uma época na qual os jornais ainda eram raros e pouco influentes, desempenhando tanto os panfletos e livros quanto as "newsletters" regularmente enviadas 'de Londres um papel fundamental na circulação de notícias. ${ }^{28}$ Não se deve estranhar, portanto, que a luta do escritor inglês por esta liberdade se tenha centrado antes no combate à censura prévia dos livros e panfletos que na crítica à censura dos jornais - a "imprensa", para a Inglaterra de Milton, consistia tão-somente em um meio de difusão de opiniões e informações, não em uma instituiçāo ou um "quarto poder". Prova-o, aliás, o próprio texto da "Order" do Longo Parlamento através da qual ressurgiu a censura prévia; com efeito, não se fez ali sequer uma única menção direta aos jornais então existentes, tão pequena era a sua importância:

"Nenhum outro livro panfleto ou escrito, nem parte de livro panfleto ou escrito serão doravante impressos (...) ou postos à venda (...), a menos que os mesmos sejam primeiro aprovados e licenciados ..."29 (grifos nossos).

28. cf. Trevelyan, ob. cit., p. 254. "Newsletters" eram cartas periodicamente enviadas a subscritores, em regra do interior do país, para informá-los dos acontecimentos em Londres e comunicar-lhes outras novidades. Este método de transmissão de informaçōes, criado pelos mercadores na Idade Média, passou, com o tempo, a ser empregado por amplos setores da sociedade inglesa.

29. Inglaterra, "Order" de 14 de junho de 1643 do Parlamento. Estabelece o controle sobre as publicações, regulamenta-o e dá outras providências. In: Milton, ob. cit., p. 196. "Nor other Book, Pamphlet, paper, nor part of any such Book, Pamphlet, or paper, shall from henceforth be printed (...) or put to sale unless the same be first approved of and licensed..." 
Até 1641, ano da abolição da famigerada "Star-Chamber", vigorou na Inglaterra o opressivo sistema de controle de publicações criado pela rainha Elizabeth; utilizado de forma implacável por Laud $^{30}$ contra os opositores das políticas externa e religiosa de Carlos $I$, tal sistema se fundava em uma regulamentação restritiva destinada sobretudo a preservar a ordem e a uniformidade na Igreja e no Estado. Havia, no entanto, mais um outro interesse, este de natureza econômica, por trás das restrições impostas - julgava-se conveniente proteger o monopólio dos vinte livreiros autorizados de Londres, permanentemente ameaçado por elementos estranhos à sua corporação. De fato, possibilitando, sem demandar despesas consideráveis, ${ }^{31}$ o acesso a um segmento do mercado então em expansão contínua, ${ }^{32}$ a edição e venda clandestina de livros constituía uma atividade bastante atrativa para os ingleses do século XVII, a despeito da perseguição governamental. Que tal perseguição não era suficiente para coibir todos os desrespeitos a seu monopólio, isto o podiam perceber os próprios livreiros londrinos; não obstante, eles a sabiam absolutamente indispensável para mantê-lo de pé. Daí o porquê de terem buscado obter do mesmo Parlamento que suprimira a "Star-Chamber" a reintrodução do sistema de licenciamento de obras que perecera juntamente com aquele órgão, graças à Revolução. Daí o porquê de terem proporcionado aos novos senhores do país um pretexto a mais para que se reinstituísse o controle de publicações, agora porém a serviço do partido presbiteriano.

A Revolução pretendia representar a negação do acentuado autoritarismo típico da monarquia Stuart e de sua versão religiosa, o anglicanismo intolerante do arcebispo Laud. Os líderes em Westminster não poderiam, ou não deveriam, conseqüentemente, "ser tão opressivos, arbitrários $e$ tirânicos como aqueles dos quais haviam libertado" os ingleses. 33 No entanto, mal se apoderou do governo, o Parlamento passou a adotar procedimentos não

30. William Laud (1573-1645), Arcebispo de Cantuária, Grande Tesoureiro, ministro e favorito de Carlos I. Figura-símbolo do absolutismo inglês, comandou as perseguiçōes aos puritanos e aos outros presbiterianos e lutou para fortalecer o poder real.

31. cf. Hill, ob. cit., p. 34. leitura.

32. Trevelyan (ob. cit., p. 254) descreve o período como de popularização dos hábitos de

33. Milton, ob. cit., p. 238. 
muito diversos dos que haviam caracterizado o regime anterior como despótico. Em junho de 1643 a contradição interna do processo revolucionário inglês foi exposta claramente em uma "Order" através da qual se regulava a impressão de livros, panfletos e outros escritos. Determinando a prisão dos autores e impressores de obras não autorizadas bem como a apreensão das mesmas, a "Order" veio a restabelecer a censura prévia, propiciando aos presbiterianos meios legais para impedir a livre difusão de informações e de idéias. Tendo levado ao fim do sistema de licenciamento dos Stuart, o Parlamento decidia implantar o seu próprio, ${ }^{34}$ confirmando-se assim, aliás, mais uma vez a identidade de interesses entre a autoridade estatal e a sempre prestigiada corporação dos livreiros, ambas unidas no desígnio comum de restringir a circulação de textos impressos.

A atitude do Longo Parlamento, embora nada representasse de incomum para a Europa de seu tempo, provocou enorme indignação em John Milton. Não que a "Order" houvesse implicado o desencadeamento de uma repressão sistemática e brutal à edição e venda clandestina de livros e outros escritos - a rigor, o controle pelo Parlamento nunca teve grande eficácia, ${ }^{35}$ tanto que a própria Areopagitica pôde ser publicada sem a devida licença. $O$ que revoltava Milton, na verdade, era a constatação do profundo divórcio existente entre as práticas políticas da oligarquia presbiteriana e o que ele julgava ser o espírito da Revolução. Para o poeta e ativista puritano, a luta pelo respeito às liberdades religiosa e intelectual do povo inglês constituía a razão de ser de todas as mudanças que o seu país atravessava; por este motivo, o futuro colaborador de Cromwell não hesitou em exigir dos antigos censurados que não se convertessem em censores, cobrando-lhes um mínimo de coerência com seu passado de combates ao despotismo.

Areopagitica foi esta cobrança; Areopagitica foi esta exigência. Mas foi também o veículo para a colocação de novas questões, muitas das quais serviriam à Teoria Política como um incitamento à conquista de um novo espaço para a reflexão. Com a obra de Milton, a problemática da liberdade de informação

34. cf. Meyer Howard Abrams (org.), The Norton Anthology of English Literature, $3^{3}$ ed., New York, W.W.Norton \& Company, 1975, p. 662.

35. Ibidem; cf. Hill, ob. cit., p. 34. 
veio por fim a ocupar um lugar central no clássico debate sobre o segredo e a transparência no Estado, tendo inclusive alguns dos argumentos do escritor seiscentista assumido a condição de autênticos alicerces do que mais tarde viria a se consolidar como uma concepção liberal de direito de informação. Naturalmente, nem todas as alegações contidas em Areopagitica podem ser dissociadas da conjuntura específica na qual Milton viveu e atuou; é mesmo forçoso admitir que muitas delas perderam todo o seu apelo, com o passar do tempo. ${ }^{36}$ Isto, todavia, em nada reduz a importância de alguns dos modos de justificação da liberdade de informação propostos pelo autor inglês. Com efeito, ao se proceder ao exame dos argumentos de Areopagitica que puderam sobreviver ao século XVII, torna-se difícil não reconhecer a enorme influência que exerceram sobre o pensamento político liberal e sobre o próprio discurso político hoje dominante nas democracias ocidentais.

Realizar este exame é necessário. Há, entretanto, que se seguir nele um critério em certa medida pessoal, quer no prévio determinar de quais argumentos mereceriam a nossa atenção, quer na escolha da forma de apresentá-los. Consistindo Areopagitica em uma peça oratória, ainda que destinada à leitura, evidentemente as idéias de seu autor não se expõem à maneira ordenada de um ensaio; cumpre assim recolhê-las do texto em que não raro aparecem dispersas e organizá-las de acordo com o que cremos ser o grau de conexidade entre elas existente. Neste trabalho, optou-se pela reunião em cinco grupos das alegações de que posteriormente se apropriaria o Liberalismo, cada qual orientado por uma idéia básica distinta, sintetizando uma das linhas mestras da argumentação de Milton:

36. Várias das alegaçōes feitas por Milton estavam tão profundamente vinculadas às circunstâncias específicas do momento histórico em que Areopagitica surgiu que, passado este, perderam a sua razão de ser. Basta lembrar, por exemplo, as alegações resultantes do freqüente recurso do autor a uma espécie de argumento de autoridade às avessas, através do qual, muitas vezes, para criticar as práticas da oligarquia presbiteriana, mostrava a semelhança destas com as adotadas por aqueles que eram os grandes vilōes para o inglês do século XVII: Laud, o Turco, a Inquisição espanhola e os "papistas" em geral. (cf. Milton, ob. cit., p. 202, 206, 208, 220, 229, 232 e 243). 
a) A censura prévia é expressão do desprezo pelos governados e da superestima da capacidade das autoridades e seus agentes.

Percebendo que a censura de algum modo se vinculava a um "menosprezo por toda pessoa instruída", 37 Milton se viu levado a concluir que todos os sistemas de licenciamento de livros e outros escritos se fundamentariam, em última análise, em um juízo preconceituoso acerca da totalidade dos governados, vistos de forma indiscriminada como carentes de tutela, por força de sua própria condição. O substrato ideológico da censura prévia consistiria, portanto, em uma presunção inadmissível - a de que existiria como que uma superioridade moral e intelectual das autoridades e seus agentes em relação ao homem comum. Rejeitando esta idéia bizarra, o escritor inglês mostrou como ela implicava, na prática, a conversão dos primeiros em tutores e a desconsideração da maturidade dos governados, com a conseqüente recondução destes últimoś à categoria dos incapazes, própria dos menores. ${ }^{38} \mathrm{~A}$ imposição da censura prévia acarretaria, dessa forma, um verdadeiro rebaixamento de todos os cidadãos, num monstruoso "vilificar da nação inteira" ${ }^{39}$

Em Areopagitica, Milton demoliu a concepção elitista que buscava legitimar o controle governamental sobre as publicações, investindo exatamente contra o que ela apresentava de menos sustentável: sua premissa de constituir o censor, por definição, uma criatura superior aos autores vigiados e a todos os supostos beneficiários das práticas tutelares do Estado. Irônico, o escritor inglês observou que a profissão de censor requeria, indubitavelmente, "um homem acima dos padrões comuns";40 um trabalho tão aviltante e tedioso como esse, no entanto, só seria capaz de atrair indivíduos estúpidos e desprezíveis, ${ }^{41}$ o que levaria a censura a padecer de uma disfunção permanente. Levantando este ponto, o autor de Areopagitica fez da ridicularização dos censores um dos motivos condutores de sua obra, visando assim a desmistificar a instituição que representavam, até então tida por inatacável.

37. Milton, ob. cit., p. 224. '... it is a particular disesteem of every knowing person...".

38. Ibid., p. 222.

39. Ibid., p. 224. '... so to me it seems an undervaluing and vilifying of the whole nation".

40. Ibid., p. 220. "... a man above the common measure".

41. Ibid., p. 221. 
Dentro desse quadro, não deixa de ser curioso registrar que, anos depois, para servir ao governo de Cromwell, o poeta inglês não hesitaria em assumir temporariamente a função de "licenser", envolvendo-se, dessa forma, com a mesma atividade que antes taxara de indigna. 42

\section{b) A censura é essencialmente liberticida.}

Uma das táticas preferenciais de Milton em seus ataques à censura consistia em alertar seus leitores para os perigos que seriam ocasionados pela concessão, a uns poucos indivíduos, de um controle quase que absoluto sobre a circulação de informações e opiniões dentro da sociedade. Para o autor de Areopagitica, tal concessão, além de ilegítima, constituiria potencialmente uma grave ameaça às liberdades, porquanto não existiriam mecanismos eficazes de proteção contra eventuais abusos de poder por parte dos censores. Não tendo eles recebido "a graça da infalibilidade e da incorruptibilidade",43 sua atuação acabaria por motivar, fatalmente, a ocorrência de arbitrariedades; por conseguinte, fazia-se necessário reconhecer o imenso perigo representado pelos "licensers" para a liberdade dos cidadãos e combater a censura como qualquer outro instrumento do despotismo.

Se o censor é sempre um pretenso "protetor" da sociedade, a quem caberá, por sua vez, protegê-la contra ele?"44 - eis uma pergunta que talvez sintetize bem muitas das preocupações expressas em Areopagitica. Realmente, para Milton, o controle sobre as publicações nunca deixou de estar associado à idéia de um poder incontrolável, que deixaria inúmeros indivíduos à mercê das autoridades que desejassem "estender seu domínio aos olhos dos homens";45 a

42. Não se deve interpretar tal fato como uma retratação; a rigor, o que nele se configurou foi apenas mais uma das incontáveis contradiçōes de Milton, exemplo clássico de intelectual bemintencionado mas incapaz de conciliar suas crenças e sua prática política.

43. Milton, ob. cit., p. 215. '... the grace of infallibility and uncorruptedness".

44. Norberto Bobbio pergunta: "Quem vigia o vigia?". Embora o pensador italiano lide com um tema incomparavelmente mais amplo, é conveniente lembrar que as questões aqui tratadas se Inserem, de certa maneira, na problemática enfocada no $5^{\circ}$ capítulo do seu $O$ futuro da democracia. (V. Norberto Bobbio, O futuro da democracia, Rio de Janeiro, Paz e Terra, 1986).

45. Milton, ob. cit., p. 206. "... extended their dominion over men's eyes". Embora a passagem extraída aparentemente se refira às tentativas da hierarquia católica de controlar e uniformizar as opiniōes dos homens através da censura, uma leitura mais atenta deixa perceber que a verdadeira intenção do autor era denunciar toda forma de censura prévia como instrumento de dominação. Para demonstrar como a censura instaurada pelo Parlamento em nada diferia da que a Igreja 
censura prévia se caracterizaria, dessa forma, por uma irreprimível vocação liberticida, pronta a se manifestar sempre que se lhe desse a oportunidade de ser exercida.

c) E a intolerância, e não a pluralidade de opinióes, que enfraquece o Estado.

Despotismo e tolerância para com contestadores são, em princípio, mutuamente excludentes. A insistência dos governos autoritários em apresentar aos governados a diversidade de opiniões como uma doença do corpo social e como um elemento desagregador deve ser entendida como parte de sua estratégia de obter pretextos para perseguir a oposição e assegurar desse modo a sua própria sobrevivência.

Se Milton não chegou a conclusões como essas, esteve sem dúvida a um passo de fazê-lo. Autor de uma das primeiras apologias do pluralismo de que se teve notícia na Idade Moderna, o escritor seiscentista rejeitou taxativamente a tese de que a diversidade de opiniões constituísse um perigoso fator de enfraquecimento do Estado; com efeito, para o poeta inglês, a unidade eventual dos diferentes grupos religiosos e políticos de que se compunha uma nação livre parecia mesmo mais sólida que a unidade artificialmente induzida pela uniformização forçada das crenças. ${ }^{46} \mathrm{~A}$ desunião debilitante seria, dentro desta linha de raciocínio, causada, em verdade, não pela coexistência de credos e tendências políticas diversas, mas sim pelos conflitos ocasionados em função das tentativas, por parte de autoridades intolerantes, de reduzi-los à homogeneidade. ${ }^{47}$ Expediente utilizado em tais tentativas de homogeneização, a censura seria assim tão contraproducente e condenável quanto elas, representando um estímulo a mais ao facciosismo nos grupos perseguidos. ${ }^{48}$

Católica impunha, Milton lançou mão de um recurso bastante engenhoso: descreveu esta última se utilizando de palavras idênticas às da "Order" que instituíra a primeira (vejam-se as últimas linhas da p. 206).

46. Cf. Milton, ob. cit, p. 236.

47. Ibid., p. 233.

48. Ibid., p. 228. 
d) A censura prévia é ineficaz, considerados os fins a que se propōe.

O quarto motivo condutor em torno do qual se desenvolve a argumentação de Areopagitica consiste, basicamente, na afirmação de que os sistemas de controle de publicações seriam incapazes de atender à finalidade que se thes costumava atribuir: ${ }^{49}$ a de favorecer a supressão das heresias e da subversão, impedindo os governados de adotarem opiniões vistas como deletérias. Segundo Milton, a idéia de que a censura prévia pudesse atuar eficazmente neste sentido resultaria, no fundo, de um superdimensionamento do poder de influência dos livros e escritos, sendo, portanto, totalmente infundada. ${ }^{50}$ Além disso, de nada adiantaria permitir apenas a impressão de textos recomendáveis ou entendidos como tal: a um leitor estúpido sempre seria possível fazer pior uso deles do que um homem sensato poderia fazer de uma obra condenável. ${ }^{51}$ Dessa forma, a censura padeceria de uma crônica ineficácia, considerados os fins a que se propunha; ${ }^{52}$ não cumprindo ela a contento a função que constituía sua razão de ser, sua existência não teria realmente o menor sentido.

A inutilidade da censura prévia ficaria ainda mais evidenciada quando o seu escopo fosse o da proteção aos chamados bons costumes. Bastante irônico, Milton observou que não valia a pena "fechar e fortificar um portāo contra a corrupção" deixando "os demais escancarados", 53 e ponderou que uma campanha governamental para coibir a imoralidade só poderia ter pleno êxito ao preço da imposição de um rigoroso controle não apenas sobre as publicações mas também sobre as próprias pessoas em seu dia-a-dia. ${ }^{54}$ Esclarecendo, em seguida, que tal controle precisaria abranger desde as roupas usadas pelos governados até as

49. Desenvolvendo esta idéia ao longo de diversas passagens de sua obra, Milton a enunciou de forma clara nas páginas 215 e 219, embora em ambas, à primeira vista, ele pareça se referir apenas ao caso concreto que examinava, qual seja, o da "Order" de 1643.

50. Cf. Milton, ob. cit., p. 214 e p. 226.

51. Ibid., p. 215.

52. Ibidem.

53. Ibidem. '... to shut and fortify one gate against corruption, and be necessitated to leave others round about wide open"

54. Ibidem. 
mais triviais conversas entre indivíduos, ${ }^{55}$ o escritor inglês demonstrou através de uma espécie de reductio ad absurdum - a total inviabilidade de sua aplicação. Dessa maneira, o respeito aos bons costumes não poderia ser assegurado pela atuação de mecanismos estatais de controle - todos estes, inclusive a censura, seriam de todo impotentes para fabricar homens virtuosos, que só poderiam mesmo surgir onde imperasse a liberdade. ${ }^{56}$

e) A censura prévia constitui um obstáculo ao avanço do conhecimento e à renovação das mentalidades.

De todas as acusações que lançou contra a censura, nenhuma parecia a Milton mais grave do que esta. Proporcionando imensos entraves à circulação de informações e opiniões, ${ }^{57}$ os sistemas de licenciamento de obras dificultariam sobremaneira o desenvolvimento do saber, ${ }^{58}$ acarretando a estagnação das mentalidades, ${ }^{59}$ o sufocar da vida intelectual e a redução de todos ao mais estúpido conformismo. ${ }^{60}$ Encarnações do obscurantismo, tais sistemas

\section{Milton, ob. cit., p. 215}

56. Anos depois de sua primeira investida contra o sistema de licenciamento, Milton diria, em sua Defensio secunda pro populo anglicano, que a liberdade era "a melhor escola da Virtude" (cf. Saurat, ob. cit., p. 158), sintetizando assim várias idéias já presentes em Areopagitica. Para o escritor puritano, ninguém se mostraria realmente virtuoso apenas por se comportar exemplarmente sob a tutela e o controle das autoridades (cf. Milton, ob. cit., p. 218); acreditava, por isso, que a censura seria absolutamente incapaz de aperfeiçoar moralmente os homens, pois ela os mantinha na ignorância do mal, quando a virtude só podia resultar do conhecimento e da rejeição deste (ibid., p. 212).

57. Prendendo-se a idéia de liberdade de informação, em Areopagitica, à de liberdade de conhecer ("liberty to know") as opiniōes alheias, pode aqui parecer, à primeira vista, desnecessário o emprego simultâneo das palavras "informação" e "opinião", a despeito do fato de não existir entre elas uma real identidade de sentido.

Não obstante, cumpre ressaltar desde logo que tais conceitos são absolutamente distintos e inconfundiveis, apesar das opiniōes poderem ser, eventualmente, veiculadas como informações, e como tal comunicadas a terceiros e a estes oferecidas como pontos de vista alternativos.

58. Interessando aqui, tão-somente, examinar o legado de Milton à tradição liberal, não é oportuno enfocar a dimensão religiosa desta sua linha de argumentação. É necessário, todavia, ter consciência de que às idéias miltonianas de "Verdade" e de "conhecimento" esteve sempre ligado um componente religioso, decorrendo disso, inclusive, o fato delas terem implicações no plano da Ética.

59. cf. Milton, ob. cit., p. 237.

60. ibid., p. 240. Na p. 226, o autor inglês invoca o exemplo da Itália para mostrar como uma nação pode mergulhar na decadência cultural em razão do estabelecimento de limitaçōes às liberdades de pensamento, de expressão e de discussão. 
inviabilizariam o intercâmbio de idéias, praticamente impedindo as pessoas de confrontarem seus pontos de vista em um debate imprescindível para a consecução de explicações mais perfeitas e de um embasamento mais sólido das conviç̧ões de cada um. Assim sendo, a censura prévia constituiria uma barreira aos avanços do conhecimento, capaz mesmo de obstar a própria busca da verdade.

A nocividade atribuída por Milton à censura prévia só pode ser dimensionada com precisão se se levar em conta a idéia que o poeta seiscentista fazia do processo de aquisição do conhecimento para ele, este se daria através de uma descoberta progressiva da verdade, em que o entrechoque de teses contrárias serviria como que para proporcionar uma depuração gradativa, em função da qual prevaleceriam sempre as proposições mais próximas do correto. Desempenhando, assim, o confronto de pontos de vista um papel fundamental no avanço rumo à verdade, qualquer obstáculo que se impusesse à difusão das opiniões representaria também, necessariamente, um obstáculo a este mesmo avanço em cada opinião, afinal, inclusive nas erradas, ${ }^{61}$ existiria sempre um potencial de colaboração à reflexão que não deveria de modo algum ser desperdiçado, quanto mais porque os homens dependeriam do exercício da Razão para se libertarem da ignorância em que se encontravam mergulhados.

Se à tradição liberal coube incorporar, no todo ou em parte, muitos dos argumentos apresentados por John Milton em sua crítica do controle governamental sobre as publicações, por outro lado ela sempre se manteve refratária ao que as reflexões do escritor seiscentista haviam gerado de mais provocador e revolucionário: o seu conceito de liberdade de informação. Demasiadamente entretido pelas polêmicas acerca da liberdade de imprensa, o Liberalismo negligenciou, ao desenvolver um conceito próprio, um aspecto fundamental da problemática das relações entre informação e cidadania - a questão da existência ou não de um efetivo acesso dos governados à informação. Neste particular, conseqüentemente, a noção liberal de liberdade de informação esteve sempre aquém da noção miltoniana; enquanto esta ao menos abria espaço 
para a elaboração de um conceito de direito de ser informado, aquela implicou uma sensível limitação dos horizontes teóricos, tendo impossibilitado por quase três séculos a construção desta essencial categoria jurídica.

Em vão se procurará em Areopagitica alguma passagem que se refira expressamente a uma "liberdade de informação" - seria, aliás, bastante ingênuo esperar de um escritor seiscentista o uso de uma terminologia adotada só recentemente. Apesar disso, não há como negar que Milton defendia em sua obra uma "liberty" na qual já se podiam vislumbrar os primeiros contornos da concepção moderna uma "liberty", por sinal, bem mais abrangente do que a simples liberdade de publicação, à qual alguns autores têm tentado reduzi-la: ${ }^{62}$

"Dai-me a liberdade de saber, de me expressar e de arguir livremente de acordo com minha consciência, acima de todas as liberdades".63

Liberdade de expressar, mas também de saber - Milton concebia a liberdade de informação como uma síntese indivisível das liberdades do sujeito emissor e do sujeito receptor. Impossível dissociá-las, como fariam os liberais, relegando uma delas a segundo plano. Impossível, também, ignorar sua interdependência. Se o escritor puritano conseguiu justificar a liberdade de publicação - núcleo da de imprensa - invocando a necessidade do respeito à "liberdade de saber", isto só foi possível porque, no fundo, ambas se apresentavam como simples faces de uma única liberdade.

Se em alguns aspectos a noção de liberdade de informação em Areopagitica constitui algo de único ou mesmo antecipa o conceito moderno, em outros ela assume nitidamente um feição pré-liberal. A caracterização, feita por Milton, desta liberdade como liberdade individual e negativa, bem o demonstra. Já dominado pela crença tipicamente liberal de que na "intromissão" estatal estaria a grande inimiga da liberdade humana, o escritor inglês entendia a liberdade de informação como um simples não-impedimento, correspondente a

62. V. Schilling, ob. cit., p. 226. Embora Milton realmente tenha sido o criador da idéia de liberdade de publicação, seu conceito đe liberdade de informação era bem mais abrangente do que Schilling dá a entender.

63. Milton, ob. cit., p. 238. "Give me the liberty to know, to utter and to argue freely according to conscience, above all liberties". 
uma situação de inércia por parte do Estado. Além disso, era incapaz de concebê-la fora de estreitos moldes individualistas. Fundando-se a sua noção de liberdade na idéia de que os "eleitos" deveriam ser livres de quaisquer restrições, Milton se via de certa maneira condicionado a adotar uma óptica individualista afinal, como bem lembra Schilling, ${ }^{64}$ "é sempre o indivíduo sozinho (...) que é o eleito".

Tendo conseguido, mesmo sem contar com o instrumental teórico adequado, realizar a difícil tarefa de construir o conceito de liberdade de informação, Milton aparentemente não chegou a conceber o seu reflexo no plano jurídico o direito à informação. ${ }^{65}$ Não lhe foi possível, por conseguinte, estabelecer uma idéia clara de direito de ser informado; com efeito, se tal idéia, ou algo próximo dela, estava presente em Areopagitica, encontrava-se ali somente implícita na argumentação, inspirando o seu autor como um sentimento indefinido. Não obstante, é preciso reconhecer que na referência do escritor seiscentista a uma "liberdade de saber" já se traía uma preocupação com o problema do acesso efetivo das pessoas à informação, o que já o colocava no rumo que seria seguido em nosso século pelos formuladores da noção de direito de ser informado. Dessa forma, há que se ver Areopagitica não apenas como o momento de criação da idéia de liberdades essenciais relativas à informação, mas também, sob certo ângulo, como um verdadeiro prenúncio, no século XVII, das tendências do pensamento jurídico contemporâneo.

64. Schilling, ob. cit., p. 224.

65. É ponto pacífico que Milton não chegou a estabelecer um verdadeiro conceito de direito à informação. Até mesmo Kurt Schilling, que afirma que o escritor seiscentista teria defendido em Areopagitica um "direito soberano fundamental" correspondente à liberdade de publicação, acaba por admitir a impossibilidade de se secularizar a idéia de tal "direito soberano" e de formulá-la em termos claros. (ibid., p. 226). 